\title{
Teknik pengekangan sapi bali dan pola sonogram jaringan untuk pendugaan kualitas karkas hidup secara ultrasonografi
}

\author{
Mokhamad Fakhrul Ulum ${ }^{1, *}$, Dairoh ${ }^{2}$, Winni Liani Daulay ${ }^{2}$, Prastya Idihastuti ${ }^{3}$, \\ Amin Wahyudiono $^{3}$, Jakaria ${ }^{2}$, Annang Dwijatmiko ${ }^{3}$ \\ ${ }^{1}$ Departemen Klinik, Reproduksi dan Patologi; Fakultas Kedokteran Hewan, IPB University, Bogor \\ ${ }^{2}$ Departemen Ilmu Produksi dan Teknologi Peternakan, Fakultas Peternakan, IPB University, Bogor \\ ${ }^{3}$ Dinas Ketahanan Pangan, Pertanian dan Perikanan (DKP3), Kota Banjarmasin, Kalimantan Selatan
}

\begin{abstract}
ABSTRAK: Pengekangan merupakan langkah awal dan utama dalam menentukan keberhasilan untuk pemeriksaan hewan, seperti pada pencitraan ultrasonografi. Tulisan ini mendeskripsikan beberapa metode pengekangan sapi bali untuk pencitraan ultrasonografi di kandang penampungan dan pola sonogram yang didapatkan. Sapi bali jantan dewasa sebanyak 101 ekor dilakukan pendugaan kualitas karkas sebelum dipotong. Pengekangan fisik dilakukan dengan pilihan yaitu: mengikat sapi pada kandang komunal, mengikat sapi kandang dengan pembatas dinding, dan menempatkan sapi pada kandang jepit. Proses pengekangan berlangsung \pm 5 -10 menit atau lebih lama tergantung temperamen sapi. Sedangkan proses pencitraan ultrasonografi berlangsung \pm 30 - 60 detik pada sudut pandang transversal dan longitudinal. Citra ultrasonografi punggung daerah rusuk 12-13 tampak ekogenitas lapisan jaringan penyusun berupa kulit, lemak subkutan, otot dan tulang punggung yang terbedakan dengan baik. Pola marbling pada sonogram otot longissimus dorsi sudut pandang transversal terlihat seperti ranting, sarang lebah, bercak-bercak, dan tanpa pola. Sedangkan citra pada sudut pandang longitudinal terlihat garis diagonal dan tanpa garis.
\end{abstract}

Kata kunci:

ultrasonografi, sapi bali, pengekangan, marbling, karkas hidup

\section{- PENDAHULUAN}

Sapi bali merupakan sapi asli Indonesia yang memiliki sifat lincah dan gesit dengan temperamen liar (Handiwarawan \& Tiesnamurti 2015), sapi bertanduk lebih liar daripada tidak bertanduk (Qayyum et al. 2020). Sapi bali memiliki potensi genetik sebagai penghasil daging berkualitas (Khasanah et al. 2016, Dairoh et al. 2021). Umumnya analisa karkas dilakukan setelah dipotong sehingga kontradiktif bagi ternak bibit. Salah satu teknik prediksi kualitas karkas pada sapi hidup adalah secara ultrasonografi (USG) (Ulum et al. 2014).

Teknik ultrasonografi bersifat non-invasif, cepat dan aman baik bagi operator, petugas pengekang serta bagi sapi (Hayanti et al. 2020). Faktor utama dalam melakukan pencitraan ditentukan pada keberhasilan pengekangan dan penganan hewan yang diperiksa. Tulisan ini menjabarkan teknik pengekangan fisik untuk USG pada sapi bali di kandang penampungan UPT Rumah Potong Hewan (RPH) Basirih Dinas Ketahanan Pangan, Pertanian dan Perikanan (DKP3) Kota Banjarmasin Kalimantan Selatan.

\section{- BAHAN DAN METODE}

Penelitian ini menggunakan 101 ekor sapi bali jantan dewasa. Air minum disediakan secara adlibitum dan pakan rumput diberikan pagi dan sore dengan pakan tambahan konsentrat dan ampas tahu. Sapi di kandang penampungan dipelihara bersamaan sapi bangsa lain dan kerbau. Ultrasonografi portable (SIUI CTS-800, China) dilengkapi transduser rektal linear $4 \mathrm{~cm}$ berfrekuensi 7,1 MHz digunakan pada pencitraan sudut pandang transversal dan longitudinal. Sapi di kekang secara fisik sesuai temperamen. Rambut punggung sisi lateral daerah torak $12-13$ dicukur seluas $\pm 5 \times 5 \mathrm{~cm}$.
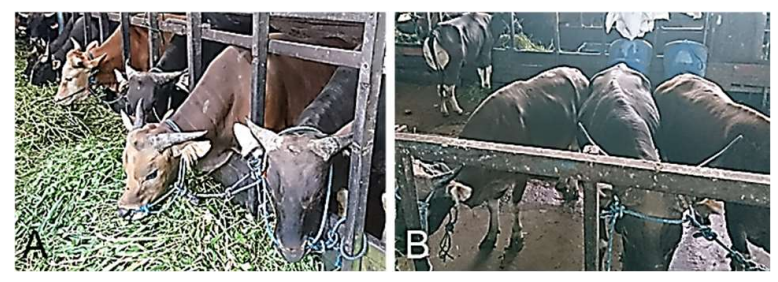

Gambar 1 Kondisi sapi bali yang ada di kandang penampungan yang diikat menggunakan (A) tali keluh dan (B) tali tanduk.

\section{- HASIL DAN PEMBAHASAN}

Teknik pengekangan dengan pendekatan berbeda pada sapi bali di kandang penampungan RPH dapat dilakukan dengan baik. Sapi kondisi diikat dengan tambang keluh dan tanduk kemudian diikat pada kandang (Gambar 1). Pengekangan tambahan dilakukan dengan mengikat tanduk dan moncong dengan tali yang ditarik ke depan atau ke atas kandang.

Diterima: 30-10-2021 | Direvisi: 01-12-2021 | Disetujui: 03-12-2021

(C) 2021 CC-BY-SA. Ini adalah artikel Open Access yang didistribusikan berdasarkan ketentuan dari Creative Commons Attribution ShareAlike 4.0 International License (https://creativecommons.org/licenses/by-sa/4.0/). 
Proses pengekangan berlangsung sekitar 5-10 menit tergantung temperamen sapi. Durasi pencitraan USG pada sapi berlangsung cepat $\pm 30-60$ detik (Gambar 2). Akan tetapi, jika sapi tidak terkekang dengan baik, maka durasi dapat menjadi lebih lama. Jika sapi terus bergerak, transduser tidak menempel dengan baik pada permukaan kulit dan gambar tidak dapat dihasilkan.
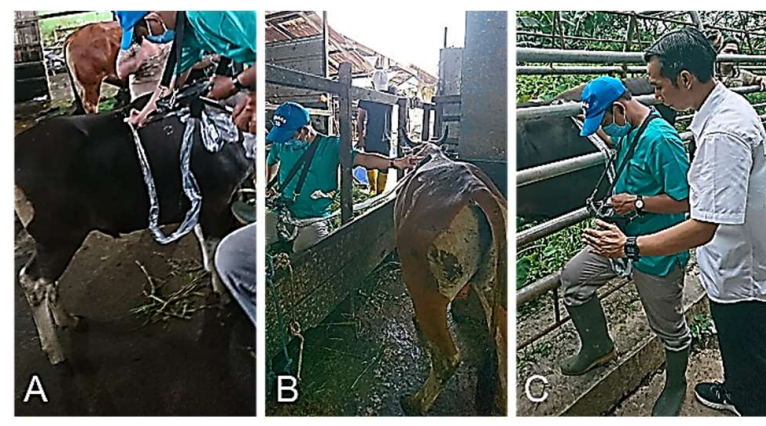

Gambar 2 Pencitraan ultrasonografi otot longissimus dorsi dengan 3 pilihan metode pengekangan: pertama (A), kedua (B), dan ketiga (C) pada sapi bali di kandang penampungan UPT RPH Basirih.

Pendekatan pertama: sapi diikat pada kandang komunal dilakukan jika kandang penuh terisi sapi. Pergerakan sapi terbatasi oleh sapi lainnya dari kedua sisi. Selain itu, karena sapi tidak dijauhkan dari kawanan, sapi merasa lebih tenang. Pencitraan dilakukan dari sisi samping depan untuk mencapai daerah pencitraan dengan waspada dari tendangan sapi yang dicitrakan ataupun sapi kawanan disebelahnya.

Pendekatan kedua: sapi diikat dikandang dengan pembatas dinding/tiang jika kondisi kandang penampungan tidak penuh. Sapi lebih bebas bergerak khususnya pada sisi kandang yang tidak terisi ternak. Sapi dipindahkan menuju sisi kandang dengan dinding/tiang pembatas. Pencitraan dilakukan dari sisi samping sejajar dengan sumbu tubuh sapi untuk mencapai daerah pencitraan.

Pendekatan ketiga: menempatkan sapi pada kandang jepit sebagai cara ideal jika tersedia. Sapi ditempatkan kandang jepit secara fisik semua arah gerakan dihalangi oleh penghalang (kayu atau besi) sehingga menjadi lebih aman. Pencitraan dilakukan dari sisi samping sejajar dengan sumbu tubuh sapi untuk mencapai daerah pencitraan.

Sonogram jaringan punggung daerah torak 12-13 tersusun atas kulit yang tampak hipoekoik, lemak subkutan tampak lebih hiperekoik, otot longissimus dorsi tampak lebih anekhoik, dan tulang punggung tampak hiperekoik. Masingmasing jaringan dapat dibedakan sesuai dengan unsur penyusunnya. Pola marbling pada sudut pandang transversal tampak membentuk pola seperti ranting, sarang lebah, dan bercak-bercak hiperekoik, maupun tidak tampak sama sekali (Gambar 3). Pola pada sudut pandang longitudinal tampak berupa garis diagonal atau tidak tampak pola. Meskipun secara penampilan terlihat gemuk, tetapi pola marbling bervariasi. Pola yang terbentuk pada otot longissimus dorsi ditentukan oleh jaringan penyusun, yaitu kombinasi serabut otot dan lemak intra muskular (Ulum et al. 2014).

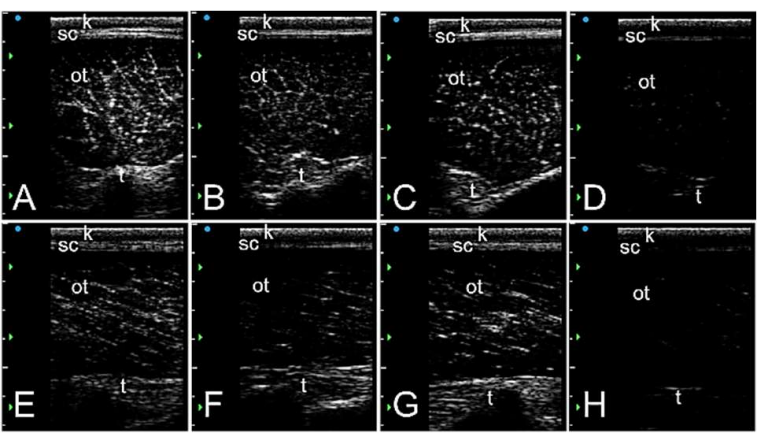

Gambar 3 Sonogram otot longissimus dorsi pada sapi bali sudut pandang transversal berupa (A) pola ranting, (B) sarang lebah, (C) pola bercak, (D) tidak terlihat pola dan sudut pandang longitudinal berupa garis diagonal $(\mathrm{E}-\mathrm{G}),(\mathrm{H})$ tidak ada garis. Keterangan: $\mathrm{k}=$ kulit, $\mathrm{sc}=$ subkutan, $\mathrm{ot}=$ otot, dan $\mathrm{t}=$ tulang.

\section{- SIMPULAN}

Teknik pengekangan sapi bali dipilih sesuai temperamen untuk memudahkan proses USG yang aman. Sonogram jaringan punggung tercitrakan dengan derajat ekogenitas dan pola marbling otot longissimus dorsi yang bervariasi.

\section{- INFORMASI PENULIS}

Penulis Korespondensi

*MFU: ulum@ipb.ac.id

Departemen Klinik, Reproduksi dan Patologi; Fakultas Kedokteran Hewan, IPB Universiti, Jln Agatis Kampus IPB Dramaga, Bogor, Jawa Barat 16680 INDONESIA

\section{- UCAPAN TERIMA KASIH}

Terima kasih kepada Kemendikbudristek melalui hibah PMDSU 2021, LPPM IPB University melalui Hibah PRKK 2021 dan UPT Rumah Potong Hewan Basirih DKP3 Kota Banjarmasin Kalimantan Selatan atas ijin pengambilan sampel penelitian.

\section{PUSTAKA ACUAN}

Dairoh D, Jakaria J, Ulum MF, Ishak AB, Sumantri C. 2021. Association of SNP g. $232 \mathrm{G}>$ T Calpain Gene with Growth and Live Meat Quality Prediction using Ultrasound Images in Bali Cattle. Jurnal Ilmu Ternak dan Veteriner. 26(2):49-56

Khasanah H, Gunawan A, Priyanto R, Ulum MF, Jakaria J. 2016. Polymorphism of myostatin (MSTN) promoter gene and its association with growth and muscling traits in Bali cattle. Media Peternakan. 39(2):95-103

Handiwarawan E, Tiesnamurti B. 2015. Pertambahan Bobot Badan Sapi Bali dan PO yang Berdasarakan Skor Temperamen. In: Prosiding Seminar Nasional Teknologi Peternakan dan Veteriner 2015:27-33.

Qayyum A, Sudirman B, Zulkharnaim. 2020. Study on the Temperament of Polled and Horned Bali Cattle. Jurnal Ilmu dan Teknologi Peternakan. 8(1):22-8.

Hayanti SY, Amrozi, Aryogi, Ulum MF. 2020. Potensi diagnostik pencitraan ultrasonografi pada otot perineal sebagai sarana diagnosa penunjang kesehatan reproduksi sapi. ARSHI Veterinary Letters. 4(2):39-40.

Ulum MF, Suprapto E, Jakaria. 2014. Ultrasonography image of longissimus dorci muscle of Bali cattle. In: Prosiding KIVNAS PDHI XIII. Palembang 23-26 November 2014 (Indonesia): Perhimpunan Dokter Hewan Indonesia; p. 368-369. 